\title{
Comparative dietary analysis of two populations of Mimagoniates rheocharis (Characidae: Glandulocaudinae) from two streams of Southern Brazil
}

\author{
Ana Paula S. Dufech, Marco A. Azevedo and Clarice B. Fialho
}

The diet of two populations of Mimagoniates rheocharis, from two freshwater streams of the rio Tramandaí, northeastern Rio Grande do Sul, Brazil, are described and compared. The specimens were collected monthly from January 1998 to March 1999, with dip nets and seine nets and preserved in $10 \%$ formalin. In laboratory, the standard length of each specimen was measured. The stomachs were removed and dissected for identification of the alimentary items. The data were analyzed using the frequency of occurrence, percent composition and index of alimentary importance methods, being the last two compared among different classes of standard length. Three methods of analysis showed the highest values for allochthonous insects, regardless the locality of collection or body size of the specimens.

As dietas de duas populações de Mimagoniates rheocharis pertencentes a dois corpos d'água do Sistema do rio Tramandaí, região nordeste do Rio Grande do Sul, Brasil, são descritas e comparadas. Os exemplares foram coletados mensalmente, entre janeiro de 1998 e março de 1999, com o auxílio de puçás e picarés e fixados em formol 10\%. No laboratório, registrou-se o comprimento padrão de cada indivíduo. Os estômagos foram retirados e dissecados para identificação dos itens alimentares. Os dados foram analisados utilizando-se os métodos de frequiência de ocorrência, composição percentual e índice de importância alimentar. Para acompanhar o efeito do tamanho dos indivíduos em sua respectiva dieta, os dados também foram analisados através de classes de comprimento padrão. Os resultados obtidos mostram claramente a predominância de insetos alóctones na dieta da espécie através dos três métodos de análise, os quais mostram altos valores para esta categoria alimentar independentemente do local de estudo ou do tamanho dos exemplares.

Key words: feeding, allochthonous insects, rio Maquiné, diet, Neotropical.

\section{Introduction}

The fish fauna of the Neotropical region is one of the most diversified in the world, recently estimated to include approximately 8000 species (Schaefer, 1998) and representing nearly $25 \%$ of world fish diversity. The Characiformes constitutes the most diverse order, being a group of fishes with a great variety of forms and behaviors (Vazzoler \& Menezes, 1992). The family Characidae comprises the largest number of known species of the order (Schaefer, 1998), being the subfamily Glandulocaudinae composed of small species of freshwater fishes, with a great variety of colors and complex courting behavior (Weitzman \& Burns, 1995). The glandulocaudines occur from the South of Costa Rica down to
Ecuador on Pacific drainage basins and down to the north of Argentina on Atlantic drainage basins (Menezes \& Weitzman, 1990). Up to now there are 50 known species distributed in 19 genera (Weitzman et al., 1988; Menezes \& Vazzoler, 1992; Weitzman et al., 1994), grouped in 7 tribes (Weitzman \& Menezes, 1998).

The genus Mimagoniates is included in the tribe Glandulocaudini and most members of this group live in water bodies bordered by remains of the Brazilian Atlantic rainforest (Weitzman et al., 1996). Mimagoniates rheocharis is one of the species of glandulocaudines recently described by Menezes \& Weitzman (1990), with little information on its biology. This species has a restricted distribution, inhabiting water bodies between the South of Santa Catarina state and

Departamento de Zoologia, Laboratório de Ictiologia, Universidade Federal do Rio Grande do Sul. Av. Bento Gonçalves, 9500. 91501970 Porto Alegre, RS, Brazil. e-mail: apdufech@ hotmail.com 
the North of Rio Grande do Sul state, Brazil (Menezes \& Weitzman, 1990).

Studies on the feeding of freshwater fishes developed in recent years have demonstrated that several species of Glandulocaudinae and other characids depend on food resources directly derived from the ciliary forests on the margin of brooks, brooklets and small rivers in general (Lowe-Mc Connell, 1987; Costa, 1987; Sabino \& Castro, 1990; Graciolli et al., 2003). According to Barrella et al. (2000), ciliary forests are fundamental components to the proper functioning of the aquatic ecosystems. Thus, changes in composition and structure of this vegetation can cause alteration in the feeding habits of freshwater fishes, affecting many links of the trophic chain.
Nelson (1964), studying different species of glandulocaudines, stated that these fishes are typically surface feeders. However, Weitzman et al. (in Weitzman \& Fink, 1985) based on occasional field observations, claimed that the tetragonopterines feed on the surface with the same frequency as the glandulocaudines when they share the same environment. Nevertheless, Graciolli et al. (2003), testing these hypotheses based on the feeding habits of two species of glandulocaudines, Diapoma speculiferum and Pseudocorynopoma doriae, and two species of tetragonopterines, Hyphessobrycon luetkenii and Astyanax fasciatus, obtained results that support Nelson's hypothesis.

The aim of this paper is to describe and compare the diet

Table 1. Frequency of occurrence of the dietary items found in the stomachs of Mimagoniates rheocharis in Station $1(\mathrm{n}=$ number of examined specimens).

\begin{tabular}{|c|c|c|c|c|c|c|c|c|c|c|c|c|c|}
\hline Alimentary Items & Mar & Apr & May & Jun & Jul & Aug & Sep & Oct & Nov & Dec & Jan & Feb & Mar \\
\hline Insecta & 100 & 100 & 100 & 100 & 100 & 100 & 100 & 100 & 100 & 100 & 100 & 100 & 100 \\
\hline Diptera & 55 & 37.5 & 55.5 & 44.4 & 80 & 26.3 & 57.9 & 46.1 & 50 & 16 & 20.5 & 25 & 85 \\
\hline Brachycera & 25 & 25 & 33.3 & 33.3 & 40 & 26.3 & 15.8 & 38.5 & - & - & 7.7 & - & 15 \\
\hline Nematocera & 30 & 12.5 & 22.2 & 22.2 & 40 & 10.5 & 26.3 & 30.8 & - & 8 & - & - & 5 \\
\hline Larvae & 15 & 12.5 & - & 11.1 & 20 & - & 21 & 15.4 & - & 12 & 12.8 & 25 & 70 \\
\hline Unidentified & 10 & 12.5 & - & - & 20 & - & 5.3 & 7.7 & - & 4 & 7.7 & 25 & 65 \\
\hline Simullidae & - & - & - & - & - & - & 10.5 & 7.7 & - & 4 & 2.6 & - & - \\
\hline Chironomidae & 5 & 12.5 & - & 11.1 & - & - & 5.3 & - & - & 8 & 2.6 & - & 10 \\
\hline Cullicidae & 5 & - & - & - & - & - & 5.3 & - & - & - & - & - & - \\
\hline Pupae & - & - & - & - & - & - & - & 7.7 & - & - & - & - & - \\
\hline Hymenoptera & 65 & 50 & 44.4 & 66.7 & 30 & 26.3 & 21 & - & 50 & 48 & 33.3 & 75 & 55 \\
\hline Formicidae & 45 & 37.5 & 33.3 & 33.3 & 10 & 21 & 5.3 & - & 50 & 28 & 25.6 & 75 & 35 \\
\hline Vespidae & 15 & - & - & - & 10 & 5.3 & - & - & 50 & - & - & - & - \\
\hline Hemiptera & - & 6.3 & 11.1 & - & 10 & - & - & 7.7 & - & 4 & 2.6 & 25 & 10 \\
\hline Terrestrial & - & - & 11.1 & - & 10 & - & - & 7.7 & - & 4 & 2.6 & 25 & - \\
\hline Aquatic & - & 6.3 & - & - & - & - & - & - & - & - & - & - & - \\
\hline Ephemeroptera (nymphs) & - & - & 11.1 & - & - & 5.3 & 5.3 & - & - & - & - & - & - \\
\hline Plecoptera & - & - & - & - & - & - & 10.5 & - & - & - & - & - & - \\
\hline Nymphs & - & - & - & - & - & - & 5.3 & - & - & - & - & - & - \\
\hline Lepidoptera (larvae) & - & - & 11.1 & - & 10 & - & 5.3 & - & - & - & - & - & - \\
\hline Coleoptera & 10 & - & 11.1 & - & 40 & 15.8 & 5.3 & - & - & 8 & 7.7 & 25 & 15 \\
\hline Terrestrial & 10 & - & 11.1 & - & 40 & 15.8 & 5.3 & - & - & - & 2.6 & 25 & 10 \\
\hline Aquatic & - & - & - & - & - & - & - & - & - & 4 & - & - & - \\
\hline Larvae & - & - & - & - & - & - & - & - & - & 4 & 5.1 & - & 5 \\
\hline Homoptera & 5 & - & - & 11.1 & 10 & - & 5.3 & 7.7 & - & - & - & - & - \\
\hline Nymphs & - & - & - & - & - & - & - & 7.7 & - & - & - & - & - \\
\hline Psocoptera & - & 6.3 & - & - & - & - & - & - & - & - & - & - & 5 \\
\hline Insect fragments & 100 & 100 & 100 & 100 & 100 & 100 & 100 & 100 & 100 & 100 & 100 & 100 & 95 \\
\hline Unidentified insects & 15 & 25 & 33.3 & - & 10 & 10.5 & 5.3 & - & - & 12 & - & - & 10 \\
\hline Unidentified insect larvae & 5 & - & 11.1 & 11.1 & - & 5.3 & - & - & - & - & - & - & 10 \\
\hline Insect eggs & 10 & 6.3 & 22.2 & - & 10 & 5.3 & - & - & - & - & 2.6 & 25 & 10 \\
\hline Collembola & 30 & 6.3 & 33.3 & 11.1 & 40 & 10.5 & 26.3 & 15.4 & - & - & 5.1 & - & 75 \\
\hline Crustacea & 50 & 12.5 & 66.7 & 22.2 & 20 & 42.1 & 15.8 & 38.5 & 100 & 12 & 5.1 & 25 & 10 \\
\hline Microcrustacea & 40 & 12.5 & 55.5 & 22.2 & 20 & 31.6 & 10.5 & 38.5 & 100 & 4 & 5.1 & - & 5 \\
\hline Isopoda & - & - & - & - & - & - & 5.3 & - & - & - & - & 25 & - \\
\hline Unidentified & - & - & 22.2 & - & - & 5.3 & - & - & - & - & - & - & - \\
\hline Acarina & 15 & 6.3 & 22.2 & - & - & - & 5.3 & 7.7 & - & 4 & 2.6 & - & - \\
\hline Araneae & 5 & - & - & 11.1 & 10 & - & 5.3 & - & - & 12 & 12.8 & 25 & 45 \\
\hline Superior plant material & 5 & 6.3 & - & 11.1 & - & - & 5.3 & 7.7 & - & 4 & 2.6 & 100 & - \\
\hline Organic matter & 85 & 75 & 88.9 & 55.5 & 70 & 68.4 & 63.2 & 92.3 & 50 & 14 & 59 & 75 & 75 \\
\hline Sediment & 5 & - & 22.2 & 22.2 & - & 10.5 & 5.3 & 15.4 & - & - & - & - & - \\
\hline $\mathrm{n}$ & 20 & 16 & 9 & 9 & 10 & 19 & 19 & 13 & 2 & 25 & 39 & 4 & 20 \\
\hline
\end{tabular}


of two populations of Mimagoniates rheocharis belonging to two water bodies of the rio Tramandaí system, in the northeastern region of Rio Grande do Sul State, Brazil, through the analysis of stomach contents. Besides that, we aim to compare the diet of individuals of different body size classes to verify possible differences in feeding.

\section{Materials and Methods}

Study Area. The present study was developed in two localities of the rio Tramandaí system, in the rio Maquiné valley, named Station 1 and Station 2. The climate is subtropical humid (Cfa), controlled by air masses of tropical and maritime polar origins, according to Köppen classification (Hasenack \& Ferraro, 1989).

Station 1 is located at the arroio Escangalhado near the locality of Barra do Ouro (29 $\left.34^{\circ} 05^{\prime \prime} \mathrm{S}, 50^{\circ} 17^{\prime} 15^{\prime \prime} \mathrm{W}\right)$. This section of the brook is characterized by a typical running water environment, with a rocky substrate, shallow waters and rapids in some areas with lentic waters in others. It has ciliary forest with tree or shrub cover and different plant composition along the brook, with considerable anthropisation, and consequent regenerating vegetation.

Station 2 is located at an unnamed brook, a tributary of the rio Maquiné, between the localities of Maquiné and Barra do Ouro (29038'06' S, 50¹4'18' W). This section is characterized by running waters at some places whilst in others there is a low current or practically still waters, with depths not exceeding $60 \mathrm{~cm}$. The bottom of the brook is constituted basically by gravel. This area has a secondary forest around it, of shrubs or ciliary size.

The sampling was done monthly between March 1998 and March 1999 at Station 1 and between January 1998 and February 1999 at Station 2, with the help of dip nets and seine nets (fishing nets with meshes of $2.5 \mathrm{~mm}$ and $5 \mathrm{~mm}$ internodes, respectively). Shortly after field collection the captured fishes were fixed in formalin $10 \%$. Voucher specimens from the studied locality are cataloged at the Fish Collection of the Departamento de Zoologia, Universidade Federal do Rio Grande do Sul, Porto Alegre, Brazil (UFRGS 5906, UFRGS 5907).

In the lab we measured the standard length of each individual. The stomachs were taken off and dissected to identify the alimentary items. The analysis was done with the help of a stereomicroscope and the organisms in the stomach contents were identified to order level and, when possible, to family level. This material was identified by consulting appropriate specialized bibliography (Borror \& Delong, 1969) and with the help of an entomologist.

The methods used for diet analysis were frequency of occurrence and the percent composition, according to Hynes (1950), and the index of alimentary importance (IAI), following Granado-Lorencio \& Garcia Novo (1981). In the frequency of occurrence method, the number of stomachs containing a certain item is expressed as the percentage of the total number of examined stomachs (Hynes, 1950). In the percent compo- sition method, the number of times each item occurred is treated as the percentage of the total number of occurrences of all items (Hynes, 1950). For this, the alimentary items were grouped in eleven taxonomic and/or broader ecological categories: allochthonous insects; autochthonous insects, including aquatic insects in the adult or larval phases of development; insect eggs; Crustacea, including specially microcrustaceans and some unidentified aquatic crustaceans; Collembola; Aracnida which includes aquatic as well as terrestrial mites and spiders; unidentified insect larvae; organic matter, including digested material of organic origin of difficult identification; superior plant material; sediment, including mineral particles; and unidentified material.

The index of alimentary importance estimates the relative importance of each alimentary category on the diet of the species. We applied a semi-quantitative abundance scale, where the contribution of each category is estimated according to the area it occupies in relation to the total content. A scale modified from Granado-Lorencio \& Garcia Novo (1981) was used: 0 - absent; 1 - scarce (less than 25\%); 2 - frequent ( 25 to less than $50 \%$ ); 3 - very frequent ( 50 to less than $75 \%$ ) and 4 - abundant (75 to $100 \%$ ). From this scale we calculated the IAI through the following formula, according to GranadoLorencio \& Garcia Novo (1981): "IAI $=\Sigma\left[\left(\mathrm{X}_{\mathrm{K}} \cdot \mathrm{k}\right) /(\mathrm{n}-1)\right]$ ", where, $\mathrm{X}_{\mathrm{k}}$ equals the frequency of occurrence of a certain component of the diet, $\mathrm{X}_{\mathrm{i}}$, with category $\mathrm{k} ; \mathrm{K}$ is the abundance category $(0,1,2,3$ and 4$)$ and $n$ is the number of categories of the scale. The values vary from 0 to 1 ; we considered main food items those with values of IAI above 0.3 , additional food items from 0.3 to 0.15 and accidental food items those with values lower than 0.15 (Guillen \& Granado, 1984). Data were evaluated monthly.

Data were also analyzed through standard length classes (SLC) to realize the effect of individual size on the diet, being established six class intervals of $6.41 \mathrm{~mm}$ of standard length: SLC1: 16.4 - 22.81 mm; SLC2: 22.82 - 29.22 mm; SLC3: 29.23 $35.63 \mathrm{~mm}$; SLC4: 35.64 - $42.02 \mathrm{~mm}$; SLC5: 42.05 - $48.45 \mathrm{~mm}$ and SLC6: 48.46 - $54.85 \mathrm{~mm}$. All six standard length classes were found in Station 1 and only four of these classes in Station 2. These groups were analyzed through methods of percent composition and index of alimentary importance.

Differences in the values of percent composition and index of alimentary importance between individuals of the two stations or different size classes were tested using the non-parametric Mann-Whitney test, Kruskal-Wallis and Dunn's test (Zar, 1999).

\section{Results}

Two hundred and five specimens were analyzed in Station 1 (16.4 - $54.85 \mathrm{~mm})$ and 124 specimens in Station 2 (19.17 $41.20 \mathrm{~mm})$.

It is possible to verify through the frequency of occurrence method (Tables 1 and 2) that the diet of the species of the two populations is constituted basically by terrestrial insects, especially of the orders Diptera and Hymenoptera. The autochthonous item Crustacea was relatively abundant in 
both collected places. Only the Order Diptera showed high frequencies at both stations and during practically all months analyzed. Insects from this Order at Station 2 appear with a higher frequency in their larval forms, whilst the contrary happens at Station 1, where adults of this insect Order appear with higher frequencies. Autochthonous insects in the early stages of development (larvae, pupae or nymphs) occur at low frequencies in most months at Station 1. Crustaceans and organic matter also showed relatively high frequencies in many months at both sampling stations.

The percent composition method (Fig. 1) revealed that the higher values were reached by terrestrial insects, which contributed with more than a third of the diet of the two populations of M. rheocharis. At Station 1, the item organic matter had the second largest value, followed by the items Crustacea and autochthonous insects. At Station 2, autochthonous insects reached the second largest value in percent composition due to the high number of insect larvae found on the diet of these individuals. The item Crustacea also had relatively high values at this station.

Analyzing the data on percent composition by standard length classes (Tables 3 and 4), there is a high frequency of terrestrial insects in all length classes for both populations.
At Station 1, the item Crustacea was more frequent on individuals of smaller size, instead of the item terrestrial insects. At Station 2, the items Crustacea and autochthonous insects had high values in practically all standard length classes, but the last item presented higher values in the two smaller classes of standard length.

Through the analysis of the index of alimentary importance for both populations (Tables 5 and 6), we verified that terrestrial insects constituted the main food item during all months. At Station 1, organic matter was considered main food item during only four months, being additional food during eight months and accidental food in only one. Autochthon insects, Collembola and superior plant material constituted additional food only during one month, and in all other months were considered as accidental or absent. Crustaceans were considered additional for two months and accidental for all others. At Station 2, however, autochthonous insects were considered main food for two months, additional food in four and accidental or absent for all others. Crustaceans constituted main food for one of the analyzed months, additional food in four and accidental or absent for all others. Organic matter was main food for one month, additional for another and accidental or absent during all the others.

Table 2. Frequency of occurrence of the dietary items found in the stomachs of Mimagoniates rheocharis in Station $2(\mathrm{n}=$ number of examined specimens).

\begin{tabular}{|c|c|c|c|c|c|c|c|c|c|c|c|c|}
\hline Alimentary Items & Jan & Mar & Apr & May & Jun & Aug & Sep & Oct & Nov & Dec & Jan & Feb \\
\hline Insecta & 100 & 100 & 100 & 100 & 100 & 100 & 100 & 100 & 100 & 100 & 100 & 100 \\
\hline Diptera & 75 & 37.5 & 85.7 & - & 75 & 66.7 & 50 & 81.3 & 100 & 57.1 & 50 & 38.5 \\
\hline Brachycera & 8.3 & 6.3 & 14.3 & - & 25 & - & - & - & - & - & - & - \\
\hline Nematocera & 8.3 & 6.3 & 7.1 & - & - & - & - & 6.3 & - & - & - & - \\
\hline Larvae & 70.8 & 25 & 71.4 & - & 25 & - & - & 75 & 100 & 57.1 & 50 & 23.1 \\
\hline Simullidae & 20.8 & 6.3 & 57.1 & - & 25 & - & - & 12.5 & - & - & 12.5 & - \\
\hline Chironomidae & 33.3 & 12.5 & 21.4 & - & - & - & - & 25 & - & 14.3 & 6.3 & - \\
\hline Unidentified & 45.8 & 6.3 & 21.4 & - & - & - & - & 37.5 & 100 & 42.9 & 37.5 & 23.1 \\
\hline Pupae & 12.5 & - & 7.1 & - & - & - & - & 6.3 & - & - & - & - \\
\hline Nymphs & 4.2 & - & 7.1 & - & - & - & - & - & - & 14.3 & - & - \\
\hline Hymenoptera & 4.2 & 12.5 & 7.1 & 14.3 & - & 33.3 & - & 25 & 50 & 14.3 & - & 15.4 \\
\hline Formicidae & - & 12.5 & 7.1 & 14.3 & - & - & - & 12.5 & 50 & - & - & - \\
\hline Plecoptera & - & - & - & - & - & 33.3 & - & - & 50 & - & - & - \\
\hline Nymphs & - & - & - & - & - & 33.3 & - & - & - & - & - & - \\
\hline Coleoptera & 4.2 & 6.3 & - & - & - & - & - & 6.3 & - & - & - & 7.7 \\
\hline Homoptera & 4.2 & - & - & - & - & - & - & - & - & - & - & - \\
\hline Insect fragments & 87.5 & 100 & 100 & 85.7 & 100 & 100 & 50 & 93.7 & 100 & 85.7 & 87.5 & 84.6 \\
\hline Unidentified insects & 12.5 & 6.3 & 14.3 & 14.3 & 50 & - & - & 12.5 & - & - & 6.3 & - \\
\hline Unidentified insect larvae & 8.3 & 6.3 & 7.1 & - & - & - & - & 12.5 & - & - & - & 7.7 \\
\hline Insects eggs & - & - & - & - & - & - & - & - & - & - & - & 7.7 \\
\hline Collembola & 20.8 & 6.3 & 42.9 & 28.6 & 25 & - & & 12.5 & - & 14.3 & 31.3 & 7.7 \\
\hline Crustacea & 29.2 & 37.5 & 71.4 & 28.6 & 25 & 33.3 & - & 43.7 & - & - & 50 & 61.5 \\
\hline Microcrustacea & 25 & 37.5 & 64.3 & - & - & - & - & 12.5 & - & - & 37.5 & 61.5 \\
\hline Unidentified & 4.2 & - & 35.7 & 28.6 & 25 & 33.3 & - & 43.7 & - & - & 18.7 & - \\
\hline Acarina & - & 12.5 & 14.3 & - & - & - & - & 6.3 & - & - & - & 7.7 \\
\hline Araneae & 8.3 & 12.5 & 14.3 & 14.3 & - & - & - & 6.3 & 50 & 14.3 & - & - \\
\hline $\begin{array}{l}\text { Superior plant material } \\
\text { Unknown origin }\end{array}$ & 4.2 & 6.3 & - & - & - & - & - & - & - & - & - & 30.8 \\
\hline Organic matter & 58.3 & 31.3 & 57.1 & 28.6 & 50 & 66.7 & 50 & 56.3 & - & 57.1 & 25 & 15.4 \\
\hline Sediment & 8.3 & - & - & - & - & 33.3 & - & - & - & - & - & - \\
\hline Unidentified material & - & - & - & - & - & - & - & - & - & 42.9 & 37.5 & 15.4 \\
\hline $\mathrm{n}$ & 24 & 16 & 14 & 7 & 4 & 3 & 2 & 16 & 2 & 7 & 16 & 13 \\
\hline
\end{tabular}




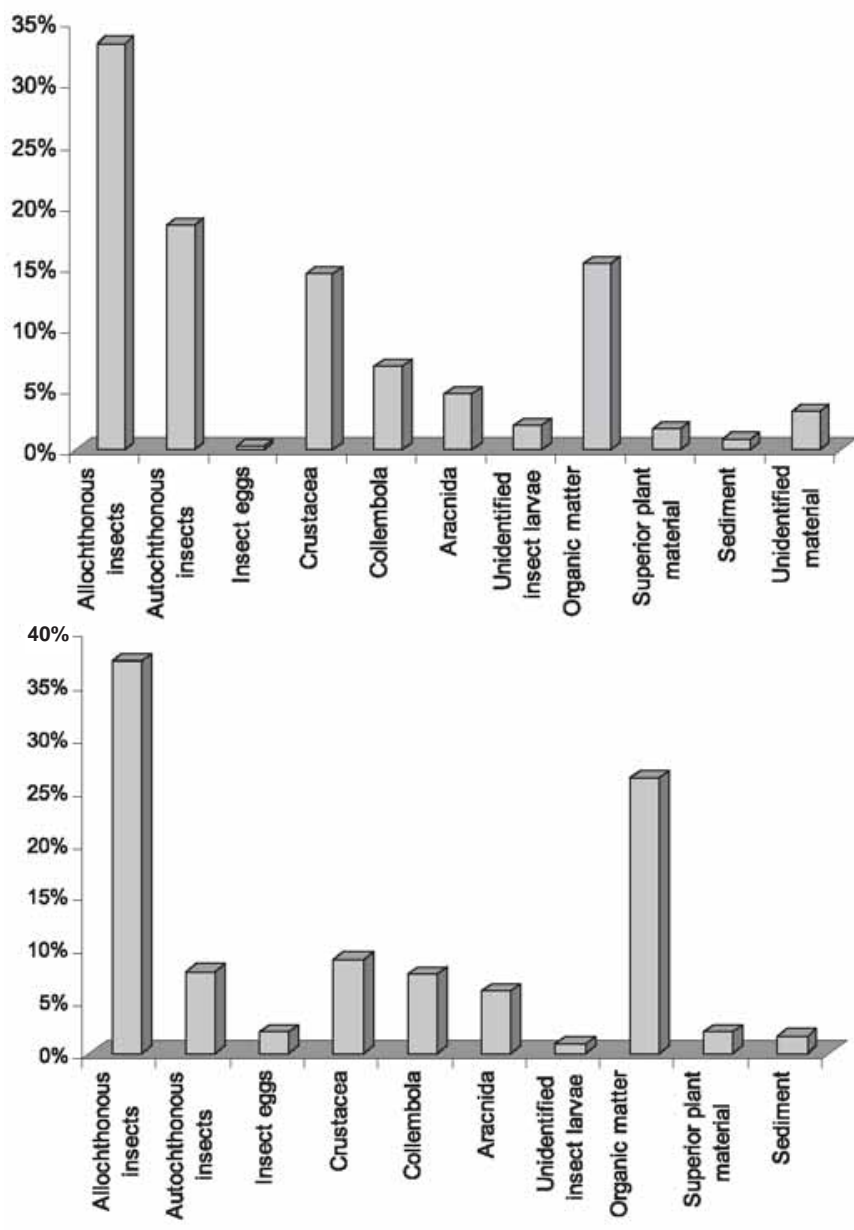

Fig. 1. Percent composition of dietary items found in the stomachs of Mimagoniates rheocharis. (a) Station 1, March 1998 to March 1999 and (b) Station 2, January 1998 to February 1999.

The non-parametric Mann-Whitney test showed that values representing autochthonous insects and Crustacea of Station 2 were significantly larger than in Station 1 ( $\mathrm{p}=$ 0.0011 and $\mathrm{p}=0.0015$, respectively). Comparing the results obtained by length classes among stations, the values observed for Collembola in the SLC1 in Station 1 were larger than those observed in Station 2 ( $\mathrm{p}=0.0087$ ). In contrast, the values observed for Crustacea in the SLC3 in Station 2 were larger than those of Station $1(\mathrm{p}=0.0008)$. The non-parametric Kruskal-Wallis test showed statistical significant differences among different standard length classes of each station, regarding allochthonous insects $(\mathrm{p}=0.0)$ in Station 1 and autochthonous insects $(\mathrm{p}=0.0185)$, Crustacea $(\mathrm{p}=0.009)$ and Collembola (0.0139) in Station 2. In Station 1, Dunn's test demonstrated that values observed for allochthonous insects in the SLC4 were significantly larger than those in the SLC2 $(\mathrm{p}<0.05)$. In Station 2, Dunn's test demonstrated that values observed for autochthonous insects were significantly larger in the SLC1 than in the SLC4 $(\mathrm{p}<0.05)$; values observed for Crustacea were significantly larger in the SLC2 than in the SLC3 ( $\mathrm{p}<0.01$ ), and values observed for Collembola were significantly larger in the SLC1 than in the SLC2 ( $<<0.05)$.
Table 3. Percent composition of dietary items found in stomachs of Mimagoniates rheocharis for standard length classes (SLC) in Station 1 (SLC1: 16.4 - 22.81 mm; SLC2: 22.82 - 29.22 mm; SLC3: 29.23 - 35.63 mm; SLC4: 35.64 - 42.02 mm; SLC5: 42.05 - $48.45 \mathrm{~mm}$ and SLC6: 48.46 - $54.85 \mathrm{~mm}$ ).

\begin{tabular}{|c|c|c|c|c|c|c|}
\hline $\begin{array}{c}\text { Alimentary } \\
\text { items }\end{array}$ & $\begin{array}{c}\text { SLC1 } \\
(\%) \\
(\mathrm{n}=13)\end{array}$ & $\begin{array}{c}\text { SLC2 } \\
(\%) \\
(\mathrm{n}=40)\end{array}$ & $\begin{array}{c}\text { SLC3 } \\
(\%) \\
(\mathrm{n}=59)\end{array}$ & $\begin{array}{c}\text { SLC4 } \\
(\%) \\
(\mathrm{n}=61)\end{array}$ & $\begin{array}{c}\text { SLC5 } \\
(\%) \\
(\mathrm{n}=20)\end{array}$ & $\begin{array}{c}\text { SLC6 } \\
(\%) \\
(n=12)\end{array}$ \\
\hline & 29.50 & 32.80 & 38.30 & 41.80 & 35.70 & 40.00 \\
\hline 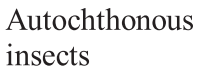 & 4.50 & 8.40 & 9.70 & 5.50 & 10.70 & 6.70 \\
\hline & 2.30 & 2.50 & 2.00 & 0.70 & 5.40 & 3.30 \\
\hline & & & & & 00 & 3.00 \\
\hline & 0 & & 7.1 & 0 & 7.10 & 6.70 \\
\hline & 4.50 & 4.20 & 9.10 & 3.40 & 5.40 & 10.00 \\
\hline $\begin{array}{l}\text { Unidenti } \\
\text { insect lar }\end{array}$ & 0.00 & 0.00 & 0.70 & 2.70 & 0.00 & 0.00 \\
\hline & 22.70 & 26.10 & 24.00 & 30.80 & 25.00 & 23.30 \\
\hline Superior plant & 2.30 & 1.70 & 1.30 & 1.40 & 3.60 & 6.70 \\
\hline Sediment & 2.30 & 2.50 & 2.00 & 1.40 & 1.70 & 0.00 \\
\hline
\end{tabular}

Table 4. Percent composition of dietary items found in stomachs of Mimagoniates rheocharis for standard length classes (SLC) in Station 2 (SLC1: 16.4 - 22.81 mm; SLC2: 22.82 - 29.22 mm; SLC3: 29.23 - 35.63 mm; SLC4: 35.64 - 42.02 mm).

\begin{tabular}{lcccc}
\hline \multicolumn{1}{c}{ Alimentary items } & $\begin{array}{c}\text { SLC1 (\%) } \\
(\mathbf{n = 3 4 )}\end{array}$ & $\begin{array}{c}\text { SLC2 (\%) } \\
(\mathbf{n}=\mathbf{4 8})\end{array}$ & $\begin{array}{c}\text { SLC3 (\%) } \\
(\mathbf{n}=\mathbf{3 0})\end{array}$ & $\begin{array}{c}\text { SLC4 (\%) } \\
(\mathbf{n}=\mathbf{1 2})\end{array}$ \\
\hline Allochthonous insects & 36.30 & 30.60 & 40.30 & 33.30 \\
Autochthonous insects & 21.50 & 20.40 & 13.00 & 12.10 \\
Insect eggs & 0.00 & 0.70 & 0.00 & 0.00 \\
Crustacea & 12.50 & 16.30 & 14.30 & 15.20 \\
Collembola & 6.70 & 7.50 & 3.90 & 12.10 \\
Aracnida & 9.20 & 4.10 & 2.60 & 0.00 \\
Unidentified insect & 2.30 & 2.00 & 2.60 & 0.00 \\
larvae & 9.20 & 15.00 & 15.60 & 18.20 \\
Organic matter & 0.00 & 3.40 & 1.20 & 0.00 \\
Superior plant material & 0.00 & 0.00 & 0.00 & 6.10 \\
Sediment & 2.30 & 0.00 & 6.50 & 3.00 \\
Unidentified material & & & & \\
\hline
\end{tabular}

\section{Discussion}

The predominance of terrestrial insects is evident in the diet of this species through any of the three methods of analysis, showing higher values for this food category regardless the studied area or the size of the specimens.

The high frequency and relative abundance of organic matter can be a result of the advanced state of decomposition of the stomach contents making impossible the identification as any other food item.

The increased values of crustaceans on the diet of the smaller length classes of Station 1 and Station 2 and of autochthonous insects in the smaller length classes of Station 2 can be a result of the feeding selectivity exerted by these fishes. The reduced opening of the mouth of the smaller individuals can make them less apt to capture large prey, 
leading them to explore smaller size resources as microcrustaceans and insect larvae. In contrast, larger individuals have the capacity of selecting larger and more caloric prey, as large insects, with lower expenditures of energy. Foraging during larval and juvenile development is selective, with the ingestion of small particles limited by mouth gap (Keeleyside, 1979, Houde, 1997 and Wooton, 1999) and locomotion ability (Wooton, 1999).

Table 5. Index of alimentary importance (IAI) of the dietary categories found in the stomachs of Mimagoniates rheocharis in Station 1 . Framed numbers $=$ main item; bold numbers $=$ additional item; simple numbers $=$ accidental item .

\begin{tabular}{lccccccc|c|c|c|c|c|c|c|c|}
\hline Alimentary Items & Mar & Apr & May & Jun & Jul & Aug & Sep & Oct & Nov & Dec & Jan & Feb & Mar \\
\hline Allochthonous insects & 0.82 & 0.77 & 0.71 & 0.89 & 0.90 & 0.88 & 0.90 & 0.81 & 1.00 & 0.93 & 0.92 & 1.00 & 0.85 \\
Autochthonous insects & 0.04 & 0.05 & 0.03 & 0.03 & 0.05 & 0.01 & 0.05 & 0.06 & 0 & 0.06 & 0.04 & 0.06 & $\mathbf{0 . 2 0}$ \\
Insect eggs & 0.02 & 0.01 & 0.05 & 0 & 0.02 & 0.01 & 0 & 0 & 0 & 0 & 0.01 & 0.06 & 0.02 \\
Crustacea & 0.14 & 0.03 & $\mathbf{0 . 1 7}$ & 0.06 & 0.05 & 0.10 & 0.04 & 0.10 & $\mathbf{0 . 2 5}$ & 0.03 & 0.01 & 0.06 & 0.02 \\
Collembola & 0.07 & 0.02 & 0.08 & 0.03 & 0.10 & 0.03 & 0.07 & 0.04 & 0 & 0 & 0.01 & 0 & $\mathbf{0 . 1 9}$ \\
Aracnida & 0.05 & 0.01 & 0.05 & 0.03 & 0.02 & 0 & 0.02 & 0.02 & 0 & 0.07 & 0.06 & 0.06 & 0.12 \\
Unidentified insect larvae & 0.01 & 0 & 0.03 & 0.03 & 0 & 0.01 & 0 & 0 & 0 & 0 & 0 & 0 & 0.01 \\
Organic matter & 0.34 & 0.41 & 0.41 & $\mathbf{0 . 2 2}$ & $\mathbf{0 . 2 5}$ & $\mathbf{0 . 2 5}$ & $\mathbf{0 . 2 3}$ & 0.38 & 0.13 & $\mathbf{0 . 1 7}$ & $\mathbf{0 . 1 8}$ & $\mathbf{0 . 1 9}$ & $\mathbf{0 . 2 1}$ \\
Superior plant material & 0.01 & 0.01 & 0 & 0.03 & 0 & 0 & 0.01 & 0.02 & 0 & 0.01 & 0.02 & $\mathbf{0 . 2 5}$ & 0 \\
Sediment & 0.01 & 0 & 0.05 & 0.05 & 0 & 0.02 & 0.01 & 0.04 & 0 & 0 & 0 & 0 & 0 \\
\hline
\end{tabular}

Table 6. Index of alimentary importance (IAI) of the dietary categories found in the stomachs of Mimagoniates rheocharis in Station 2 . Framed numbers $=$ main item; bold numbers $=$ additional item; simple numbers $=$ accidental item .

\begin{tabular}{lccccccccccccccccc}
\hline Alimentary Items & Jan & Mar & Apr & May & Jun & \multicolumn{1}{c}{ Aug } & Sep & \multicolumn{1}{c}{ Oct } & Nov & Dec & Jan & Feb \\
\hline Allochthonous insects & 0.73 & 0.94 & 0.73 & 0.75 & 1 & 0.75 & 1 & 0.64 & 0.87 & 0.78 & 0.84 & 0.83 \\
Autochthonous insects & $\mathbf{0 . 2 8}$ & 0.06 & $\mathbf{0 . 2 3}$ & 0 & 0.06 & 0.08 & 0 & 0.3 & 0.37 & $\mathbf{0 . 2 1}$ & $\mathbf{0 . 1 6}$ & 0.13 \\
Insect eggs & 0 & 0 & 0 & 0 & 0 & 0 & 0 & 0 & 0 & 0 & 0 & 0.04 \\
Crustacea & 0.08 & 0.09 & 0.32 & $\mathbf{0 . 1 8}$ & 0.06 & 0.08 & 0 & $\mathbf{0 . 2 5}$ & 0 & 0 & $\mathbf{0 . 1 7}$ & $\mathbf{0 . 1 5}$ \\
Collembola & 0.05 & 0.02 & 0.12 & 0.12 & 0.06 & 0 & 0 & 0.03 & 0 & $\mathbf{0 . 2 1}$ & 0.08 & 0.02 \\
Aracnida & 0.02 & 0.06 & 0.07 & 0.07 & 0 & 0 & 0 & 0.03 & 0.12 & $\mathbf{0 . 2 1}$ & 0 & 0.02 \\
Unidentified insect larvae & 0.01 & 0.05 & 0.02 & 0 & 0 & 0 & 0 & 0.03 & 0 & 0 & 0 & 0 \\
Organic matter & $\mathbf{0 . 1 9}$ & 0.11 & 0.14 & 0.12 & 0.12 & 0.41 & 0.12 & 0.14 & 0 & 0.14 & 0.05 & 0.04 \\
Superior plant material & 0.01 & 0.02 & 0 & 0 & 0 & 0 & 0 & 0 & 0 & 0 & 0 & 0.1 \\
Sediment & 0.02 & 0 & 0 & 0 & 0 & 0.08 & 0 & 0 & 0 & 0 & 0 & 0 \\
Unidentified material & 0 & 0 & 0 & 0 & 0 & 0 & 0 & 0 & 0 & 0.12 & 0.09 & 0.04 \\
\hline
\end{tabular}

Table 7. Index of alimentary importance (IAI) of the dietary categories found in the stomachs of Mimagoniates rheocharis for standard length classes (SLC) in Station 1. (SLC1: 16.4 - $22.81 \mathrm{~mm}$; SLC2: 22.82 - 29.22 mm; SLC3: 29.23 $35.63 \mathrm{~mm}$; SLC4: 35.64 - $42.02 \mathrm{~mm}$; SLC5: 42.05 - $48.45 \mathrm{~mm}$ and SLC6: 48.46 - $54.85 \mathrm{~mm}$ ). Framed numbers = main item; bold numbers $=$ additional item; simple numbers $=$ accidental item .

\begin{tabular}{|c|c|c|c|c|c|c|}
\hline Alimentary Items & $\begin{array}{l}\text { SLC1 } \\
(\mathrm{n}=13)\end{array}$ & $\underset{(n=40)}{\text { SLC2 }}$ & $\begin{array}{l}\text { SLC3 } \\
(\mathrm{n}=59)\end{array}$ & $\begin{array}{c}\text { SLC4 } \\
(\mathrm{n}=61)\end{array}$ & $\begin{array}{l}\text { SLC5 } \\
(\mathrm{n}=\mathbf{2 0})\end{array}$ & $\begin{array}{l}\text { SLC6 } \\
(\mathrm{n}=12)\end{array}$ \\
\hline Allochthonous insects & 0.89 & 0.76 & 0.87 & 0.90 & 0.94 & 0.93 \\
\hline Autochthonous insects & 0.04 & 0.08 & 0.07 & 0.03 & 0.07 & 0.04 \\
\hline Insect eggs & 0 & 0.01 & 0.01 & 0.01 & 0.04 & 0.02 \\
\hline Crustacea & 0.19 & 0.10 & 0.04 & 0.04 & 0.04 & 0.02 \\
\hline Collembola & 0.15 & 0.05 & 0.05 & 0.03 & 0.05 & 0.04 \\
\hline Aracnida & 0.08 & 0.04 & 0.08 & 0.03 & 0.04 & 0.06 \\
\hline Unidentified insect larvae & 0 & 0 & 0.01 & 0.02 & 0 & 0 \\
\hline Organic matter & 0.23 & 0.35 & 0.20 & 0.26 & 0.21 & 0.18 \\
\hline Superior plant material & 0.02 & 0.01 & 0.02 & 0.01 & 0.02 & 0.04 \\
\hline Sediment & 0.02 & 0.02 & 0.01 & 0.01 & 0.01 & 0 \\
\hline
\end{tabular}

Table 8. Index of alimentary importance (IAI) of the dietary categories found in the stomachs of Mimagoniates rheocharis for standard length classes (SLC) in Station 2. (SLC1: 16.4 - $22.81 \mathrm{~mm}$; SLC2: 22.82 - 29.22 mm; SLC3: 29.23 $35.63 \mathrm{~mm}$; SLC4: $35.64-42.02 \mathrm{~mm}$. Framed numbers = main item; bold numbers $=$ additional item; simple numbers $=$ accidental item.

\begin{tabular}{lcccc}
\hline Alimentary Items & $\begin{array}{c}\text { SLC1 } \\
(\mathbf{n}=\mathbf{3 4})\end{array}$ & $\begin{array}{c}\text { SLC2 } \\
(\mathbf{n}=\mathbf{4 8})\end{array}$ & $\begin{array}{c}\text { SLC3 } \\
(\mathbf{n}=\mathbf{3 0})\end{array}$ & $\begin{array}{c}\text { SLC4 } \\
(\mathbf{n}=\mathbf{1 2})\end{array}$ \\
\hline Allochthonous insects & 0.76 & 0.79 & 0.76 & 0.78 \\
\cline { 2 - 5 } Autochthonous insects & $\mathbf{0 . 2 2}$ & $\mathbf{0 . 2 0}$ & 0.01 & 0.08 \\
Insect eggs & 0 & 0.01 & 0 & 0 \\
Crustacea & 0.14 & $\mathbf{0 . 1 5}$ & $\mathbf{0 . 2 0}$ & $\mathbf{0 . 2 0}$ \\
Collembola & 0.04 & 0.06 & 0.03 & 0.08 \\
Aracnida & 0.06 & 0.03 & 0.02 & 0 \\
Unidentified insect larvae & 0.06 & 0.01 & 0.02 & 0 \\
Organic matter & 0.10 & 0.13 & 0.12 & $\mathbf{0 . 2 1}$ \\
Superior plant material & 0 & 0.03 & 0.08 & 0 \\
Sediment & 0 & 0.01 & 0 & 0.04 \\
Unidentified material & 0.02 & 0.02 & 0.04 & 0.02 \\
\hline
\end{tabular}


No accentuated differences were observed in the diet of the species in the two populations evaluated since terrestrial insects constituted the main food item in both stations. However, there was an increase in autochthon insects at Station 2, which can be attributed to differences in the food availability between the two analyzed stations. According to Azevedo (2000), at Station 2 there is a spatial segregation between $M$. rheocharis and M. microlepis, with the latter occupying larger and more stable lentic water portions between rapids and $M$. rheocharis restricted to smaller still water portions, near to the rapids. That situation could cause a difference in the food availability between these different microhabitats, interfering, thus, in the diet of the species. Such segregation is not observed at Station 1 , since $M$. rheocharis is the only species of this genus found therein.

Studies involving other species of Mimagoniates and other Glandulocaudines reveal similar results. Costa (1987) studying $M$. microlepis observed that it is a surface feeding and that 70 to $90 \%$ of its diet is composed of terrestrial arthropods. Sabino \& Castro (1990) and Lampert et al. (2003) studying the same species and Graciolli et al. (2003), studying other glandulocaudines, reached similar results, corroborating the stated importance of terrestrial insects on the diet of these fishes. These studies also show the importance of the ciliary forest around the water bodies as a food source for the environment.

Lowe-McConnell (1987) asserts that allochthonous items, including terrestrial insects, are of great importance for fishes feeding on turbulent rivers, margined by forests. It is also worth mentioning the importance of aquatic insects on the diet of some fishes. These observations are in agreement with the results obtained here.

These results, besides showing the role of terrestrial insects and ciliary forests around rivers and brooks for the feeding of different species of fishes, demonstrate the interdependence between the aquatic and terrestrial environments, suggesting that the characteristics of a water body influence not only the aquatic community but also the terrestrial animal community of the environs.

Our results also corroborate Nelson's hypothesis (1964) that Glandulocaudinae feed mainly at the surface, assuming that insects, as well as other allochthonous invertebrates, when fall into a water body, stay on the surface until captured.

\section{Conclusion}

In this paper we showed that two populations of Mimagoniates rheocharis here studied feed basically on allochthonous insects, with the species characterized as insectivorous. The eventual variations on the species diet can be attributed to differences in the environment, in the availability of food and on the size of the individuals. We also showed that the surface feeding is typical for the species given the nature of the consumed items and we add strength to the hypothesis that the glandulocaudines are characterized by this feeding pattern. We observed that forest environments around the sampled areas are directly responsible for the feeding and survival of the populations of $M$. rheocharis studied here.

\section{Acknowledgments}

We are grateful to Dr. Luiz R. Malabarba for comments on the manuscript and to colleagues of the Laboratório de Ictiologia for their help during field work and to Nora Fortes of the Laboratório de Entomologia of the Departamento de Zoologia, UFRGS, for help in identifying the insects. To FAPERGS - Fundação de Amparo à Pesquisa do Estado do Rio Grande do Sul (proc. 01511105) and CNPq - Conselho Nacional de Desenvolvimento Científico e Tecnológico (proc. 103185/98-4) for the scholarships given to senior author. Financial support was provided by CNPq (Proc. 464545/00-5).

\section{Literature Cited}

Azevedo, M. A. 2000. Biologia reprodutiva de dois glandulocaudíneos com inseminação, Mimagoniates microlepis e Mimagoniates rheocharis (Teleostei: Characidae), e características de seus ambientes. Unpublished M. Sc. Dissertation, Universidade Federal do Rio Grande do Sul, Porto Alegre, Brazil, 84 p.

Barrella, W., M. Petrere Jr., W. S. Smith \& L. F. de A. Montag. 2000. As relações entre matas ciliares, os rios e os peixes. Pp 187-207. In: R. R. Rodrigues \& H. de F. Leitão Filho (eds). Matas Ciliares: conservação e recuperação. Edusp/ Fapesp, São Paulo, 320 p.

Borror, D. J. \& D. M. Delong. 1969. Introdução ao estudo dos insetos. Agência norte-americana para o desenvolvimento internacional, Rio de Janeiro, Rio de Janeiro, $653 \mathrm{p}$.

Costa, W. J. E. M. 1987. Feeding habits of a fish community in a tropical coastal stream, rio Mato Grosso, Brazil. Studies on Neotropical Fauna and Environment, 22(3): 145-153.

Graciolli, G., M. A. Azevedo \& F. A. G. de Melo. 2003. Comparative study of the diet of Glandulocaudinae and Tetragonopterinae (Ostariophysi: Characidae) in a small stream in southern Brazil. Studies on Neotropical Fauna and Environment, 38(2): 95-103.

Granado-Lorencio, C. \& F. Garcia Novo. 1981. Feeding habits of the fish community in a eutrophic reservoir in Spain. Ekologia Polska, 34(1): 95-110.

Guillen, E. \& C. Granado. 1984. Alimentación de la ictiofauna del embalse de torrejon (Rio Tajo, Caceres). Limnética, 1:304-310.

Hasenack, H. \& L. W. Ferraro. 1989. Considerações sobre o clima da região de Tramandaí, RS. Pesquisas, 22:53-70.

Houde, E. D. 1997. Patterns and consequences of selective processes in teleost early life histories. Pp 173-196. In: C. Chambers \& E. A. Trippel (ed). Early life history and recruitment in fish population. London: Chapman \& Hall, $632 \mathrm{p}$. 
Hynes, H. B. N. 1950. The food of freshwater sticklebacks (Gasterosteus aculeatus and Pygosteus pungintius), with a review of methods used in studies of the food fishes. Journal of Animal Ecology, 19:36-57.

Keenleyside, M. H. A. 1979. Zoophysiology, diversity and adaptation in fish behavior. Berlin: Springer-Verlag, $208 \mathrm{p}$.

Lampert, V. R., M. A. Azevedo \& C. B. Fialho. 2003. Hábito alimentar de Mimagoniates microlepis Steidachner, 1876 (Characidae, Glandulocaudinae) do canal de ligação entre as lagoas Emboaba e Emboabinha, Osório, RS. Comunicações do Museu de Ciências e Tecnologia da PUCRS, Sér. Zoologia, 16(1): 3-16.

Lowe-McConnell, R. H. 1987. Ecological studies in tropical fish communities. Cambridge, University Press Cambridge, XIII + 382p.

Menezes, N. A. \& A. E. de M. Vazzoler. 1992. Reproductive characteristics of Characiformes. Pp 60-70. In: W. C. Hamlett (ed): Reproductive biology in the South American vertebrates, New York: Springer-verlag, 328p.

Menezes, N. A. \& S. H. Weitzman. 1990. Two new species of Mimagoniates (Teleostei: Characidae: Glandulocaudinae), their phylogeny and biogeography and a key to the glandulocaudin fishes of Brazil and Paraguay. Proceedings of the Biological Society of Washington, 103: 380-426.

Nelson, K. 1964. Behavior and morphology in the glandulocaudine fishes (Ostariophysi, Characidae). University of California, Publications in Zoology, 75: 59-152.

Sabino, J. \& R. M. C. e Castro. 1990. Alimentação, período de atividade e distribuição espacial dos peixes de um riacho da floresta Atlântica (sudeste do Brasil). Revista Brasileira de Biologia, 50(1): 23-26.

Schaefer, S. A. 1998. Conflict and resolution: impact of new taxa on phylogenetic studies of Neotropical cascudinhos (Siluroidei: Loricariidae). Pp. 375-400. In: L. R. Malabarba, R. E. Reis, R. P. Vari, Z. M. S. Lucena \& C. A. S. Lucena (eds.), Phylogeny and classification of Neotropical fishes, Porto Alegre Edipucrs, 603p.

Vazzoler, A. E. A. de M. \& N. A. Menezes. 1992. Síntese dos conhecimentos sobre o comportamento reprodutivo dos Characiformes da América do Sul (Teleostei, Ostariophysi). Revista Brasileira de Biologia, 52(4): 627-640.
Weitzman, S. H. \& J. R. Burns 1995. Glandulocaudine fishes: a brief history from the perspective of the biologist/ aquarist. Tropical Fish Hobbyist, 44(2): 102104,106,108,110-113.

Weitzman, S. H., N. A. Menezes \& J. R. Burns. 1996. Species of the glandulocaudine tetra tribe Glandulocaudini: comments from ongoing research. Tropical Fish Hobbyist, 44(4):100-102,104,106-108.

Weitzman, S H. \& N. A. Menezes. 1998. Relationships of the tribes and genera of the Glandulocaudinae (Ostariophysi: Characiformes: Characidae) with a description of a new genus, Chrysobrycon. Pp 155-176. In: L. R. Malabarba, R. E. Reis, R. P. Vari, Z. M. S. Lucena \& C. A. S. Lucena (eds.). Phylogeny and classification of Neotropical fishes. Porto Alegre, Edipucrs, 603p.

Weitzman, S. H., N. A. Menezes \& M. J. Weitzman. 1988. Phylogenetic biogeography of the Glandulocaudini (Teleostei, Characiformes, Characidae) with comments on the distribution of the other freshwater fish in eastern and southeastern Brazil. Pp 379-427. In: W. R. Heyer \& P. E. Vanzolini (eds.). Proceedings of a workshop on Neotropical distribution patterns. Rio de Janeiro. Academia Brasileira de Ciências, 488p.

Weitzman, S. H., S. V. Fink, A. Machado-Allison \& R. Royero L. 1994. A new genus and species of Glandulocaudinae (Teleostei, Characidae) from southern Venezuela. Ichthyological Exploration of Freshwaters, 5: 45-54.

Weitzman, S. H, S. V. Fink \& N. A. Menezes. 1985. A critique of the monophyly of the Glandulocaudinae. Pp. 112-117. In: S. H. Weitzman \& S. V. Fink (eds.), Xenurobryconin phylogeny and putative pheromone pumps in glandulocaudine fishes (Teleostei, Characidae). Smithsonian Contributions to Zoology, 421:1-121.

Wooton, R. J. 1999. Ecology of teleost fish. The Netherlands: Kluwer Academic Publishers, 386p.

Zar, J. H. 1999. Bioestatistical analysis. 4th ed. Northern Illinois University. Prentice Hall, New Jersey. 212 p.

Received June 6, 2003 Accepted September 26, 2003 